\title{
Long-term monitoring of the arrival, expansion and effects of the alien mussel Mytilus galloprovincialis relative to wave action
}

\author{
George M. Branch", Francois Odendaal, Tamara B. Robinson \\ Marine Biology Research Centre, Zoology Department, University of Cape Town, Rondebosch 7701, South Africa
}

\begin{abstract}
The Mediterranean mussel Mytilus galloprovincialis is the most widespread marine alien species along the South African coast. Long-term monitoring of the mid-to-low intertidal zone in the Groen-Spoeg area on the west coast between 1988 and 1993 tracked the establishment and expansion of this aggressive invader along a gradient of wave action. Additionally, the effects of M. galloprovincialis on other dominant species were quantified. The rate of increase and abundance of $M$. galloprovincialis was promoted by exposure to strong wave action. The tube-building polychaete Gunnarea capensis remained the dominant space occupier on sheltered shores but its density was negatively correlated with the M. galloprovincialis expansion on semi-exposed and exposed shores. In contrast, the indigenous mussel Aulacomya ater demonstrated no significant changes in density over time as it simply became incorporated into the spreading M. galloprovincialis beds. Overall abundance of the grazing limpet Scutellastra granularis was positively affected by the M. galloprovincialis invasion, although adults and recruits occupying primary space showed a negative correlation with M. galloprovincialis abundance, the strength of which increased with wave exposure. Conversely, adults and recruits occurring on secondary space were positively affected by M. galloprovincialis beds, which enhanced settlement. Again the strength of the interaction increased with wave action. Patterns observed in the field therefore indicated that abundance of M. galloprovincialis and its effects on other elements of the fauna were linked with the intensity of wave action.
\end{abstract}

KEY WORDS: Mytilus galloprovincialis · Invasive species · Wave action

\section{INTRODUCTION}

Marine alien species are widely acknowledged as a major threat to biodiversity and the functioning of ecosystems within the world's oceans (Mack et al. 2000, Sala et al. 2000, Grosholz 2002, Olenin et al. 2007). In contrast to many other regions, only 21 alien marine species are known from South African shores (Robinson et al. 2005). Of these, the Mediterranean mussel Mytilus galloprovincialis is the most widespread and ecologically important, occupying over $2000 \mathrm{~km}$ of the South African coast (Robinson et al. 2005). This species has invaded areas along the Japanese (Wilkins et al. 1983), Korean (Suh \& Choi 1990), Australian (McDon- ald et al. 1991), Mexican (Ramirez \& Cáceros-Martinez 1999), Irish (Gosling \& Wilkins 1981) and North American coasts (Rawson et al. 1999) and was first recorded along the South African west coast in 1979. Since then it has become a dominant intertidal species in the region.

Within this region Mytilus galloprovincialis has largely displaced the indigenous mussels Choromytilus meridionalis and Aulacomya ater (Hockey \& van Erkom Schurink 1992), while exhibiting partial habitat segregation with the local mussel Perna perna on the south coast (Rius \& McQuaid 2006). Extremely high recruitment rates of up to 8.7 million recruits $\mathrm{m}^{-2}$ along the west coast (Robinson et al. 2007a) have enabled 
M. galloprovincialis to dominate primary rock surfaces, significantly altering overall community structure (Robinson et al. 2007b) and negatively affecting various competitively inferior limpet species (Branch \& Steffani 2004). By excluding the limpet Scutellastra granularis from open rock, M. galloprovincialis has reduced the number of individuals occurring on primary rock space. However, overall $S$. granularis density has increased due to the favourable settlement and recruitment substratum offered by M. galloprovincialis beds (Griffiths et al. 1992, Hockey \& van Erkom Schurink 1992). In the extreme low-shore areas the limpet Scutellastra argenvillei also competes with M. galloprovincialis for space (Steffani \& Branch 2005). The strength of this interaction is, however, strongly mediated by wave action (Steffani \& Branch 2003a,b). On exposed shores, high growth rates and prolific recruitment enable M. galloprovincialis to outcompete $S$. argenvillei and dominate primary substratum. However, on semi-exposed shores, the mussel's competitive ability is much reduced and $S$. argenvillei maintains dominance of open rock space (Steffani \& Branch 2003a,b,c, Branch \& Steffani 2004).

The gregarious tube-building polychaete Gunnarea capensis occurs along the entire South African coast. Most abundant on sheltered shores, this dominant space occupier forms intertidal reefs of sandy tubes. Although not formally quantified before the present study, settlement of this species is thought to be sporadic with populations demonstrating dramatic fluctuations over time.

In 1988, an intertidal monitoring programme was initiated on rocky shores in the area between the Groen and Spoeg rivers on the South African west coast, in the context of a proposed marine protected area (Emanuel et al. 1992). This coincided with the arrival of Mytilus galloprovincialis along this stretch of coast and presented a unique opportunity to study the arrival, recruitment, expansion and interspecific interactions of this aggressive invader. Because the observations spanned a wide range of wave action this also allowed analysis of how wave action moderates such invasions.

In context of the mid to low shore zones where Mytilus galloprovincialis is concentrated, the following a priori hypotheses were constructed: (1) M. galloprovincialis recruitment and rate of expansion would increase with wave action. (2) M. galloprovincialis would negatively affect Gunnarea capensis, with greater intensities at high levels of wave action that favour M. galloprovincialis growth and recruitment and disfavour G. capensis growth and recruitment. (3) Recruitment of both M. galloprovincialis and G. capensis would be positively associated with conspecific adults (Pawlick 1988, Harris et al. 1998, Robinson et al. 2007a). (4) M. galloprovincialis would negatively affect
Scutellastra granularis adults as they principally occur on primary rock space, which would be overgrown by M. galloprovincialis. Conversely, M. galloprovincialis would have a positive effect on $S$. granularis recruits as encroaching mussel beds offer secondary habitat suitable for settlement (Griffiths et al. 1992). Both these effects were predicted to increase in strength with increasing wave action. (5) The indigenous mussel Aulacoma ater would be negatively affected by M. galloprovincialis as the needs for primary substrate, food and wave action by both species overlap (Robinson et al. 2007b). (6) Foliar algae would be favoured in sheltered areas (McQuaid \& Branch 1984, Bustamante et al. 1997) where M. galloprovincialis has the least effect and $G$. capensis aids recruitment by inhibiting grazers. Our studies address these hypotheses by describing patterns observed in the field over a 6 yr period.

\section{MATERIALS AND METHODS}

The study was conducted in the Groen-Spoeg area $600 \mathrm{~km}$ north of Cape Town along the west coast of South Africa in the Namaqua biogeographic region (Emanuel et al. 1992). The area experiences relatively persistent upwelling and is dominated by cool nutrient-rich waters (Shannon 1985, Wieters 2006) that support a highly productive intertidal zone (Bustamante et al. 1995a,b). Due to the physical heterogeneity of the coastline, wave exposure varies markedly over spatial scales of between tens and hundreds of meters (Steffani \& Branch 2003a, Wieters 2006).

Six sites occurring within a $5 \mathrm{~km}$ section of coastline were monitored (Table 1), with 20 permanent plots of $0.35 \mathrm{~m} \times 0.5 \mathrm{~m}$ (i.e. $0.18 \mathrm{~m}^{2}$ ) being established at each site within the mid- to low-shore areas and between mid-tide and low-water neap levels. During the $6 \mathrm{yr}$ of monitoring a number of plots were lost, resulting in full data sets for between 12 and 20 plots per site. Wave force was measured simultaneously at each plot using maximum wave-force dynamometers (Palumbi 1984).

Table 1. Geographical locations and distribution of plots among the 6 sites in this study

\begin{tabular}{|lcccc|}
\hline \multirow{2}{*}{ Site } & \multirow{2}{*}{$\begin{array}{c}\text { Geographical } \\
\text { coordinates }\end{array}$} & \multicolumn{4}{c|}{\begin{tabular}{c} 
Sumber of plots \\
\cline { 3 - 5 }
\end{tabular}} & & \multicolumn{4}{c}{$\begin{array}{c}\text { Sheltered } \\
\text { exposed }\end{array}$} \\
\hline $\mathrm{A}$ & $30^{\circ} 54.926^{\prime} \mathrm{S}, 17^{\circ} 36.169^{\prime} \mathrm{E}$ & 3 & 6 & 8 \\
$\mathrm{~B}$ & $30^{\circ} 54.833^{\prime} \mathrm{S}, 17^{\circ} 36.240^{\prime} \mathrm{E}$ & 12 & - & - \\
$\mathrm{C}$ & $30^{\circ} 54.831^{\prime} \mathrm{S}, 17^{\circ} 36.220^{\prime} \mathrm{E}$ & 4 & 9 & 4 \\
$\mathrm{D}$ & $30^{\circ} 54.342^{\prime} \mathrm{S}, 17^{\circ} 35.472^{\prime} \mathrm{E}$ & 4 & 6 & 6 \\
$\mathrm{E}$ & $30^{\circ} 53.752^{\prime} \mathrm{S}, 17^{\circ} 35.764^{\prime} \mathrm{E}$ & 7 & 5 & 4 \\
$\mathrm{~F}$ & $29^{\circ} 15.300^{\prime} \mathrm{S}, 16^{\circ} 52.245^{\prime} \mathrm{E}$ & 20 & - & - \\
\hline
\end{tabular}


Measurements were taken on 5 successive days during winter and averaged to obtain a mean measure of maximum wave action. Wave forces spanned 2.25 to $12.87 \times 10^{3} \mathrm{~N} \mathrm{~m}^{-2}$ and were used to classify individual plots as 'sheltered' (2 to $\left.5.5 \times 10^{3} \mathrm{~N} \mathrm{~m}^{-2}\right)$, 'semiexposed' (5.6 to $\left.7.5 \times 10^{3} \mathrm{~N} \mathrm{~m}^{-2}\right)$ or 'exposed' $(>7.5 \times$ $10^{3} \mathrm{~N} \mathrm{~m}^{-2}$ ). No plots fell within the 'extremely exposed' category as defined by Steffani \& Branch (2003a).

Plots were sampled non-destructively ca. 4 times a year from 1988 to 1993. At each sampling period percent cover of Mytilus galloprovincialis, Gunnarea capensis and the dominant algal species (i.e. Ulva spp., Porphyra capensis, Caulacanthus ustulatus and Aeodes orbitosa), and numbers of $M$. galloprovincialis, G. capensis, Aulacomya ater and Scutellastra granularis were recorded. The densities of recruits were also recorded, with 'recruits' being defined by size as follows: M. galloprovincialis, A. ater and S. granularis $<10 \mathrm{~mm}$; G. capensis <2 mm internal tube diameter. Although it is not possible to accurately count total numbers of recruits non-destructively, a pilot study demonstrated that non-destructive sampling gave accurate relative counts of recruits between species and plots, although it underestimated absolute densities. Annual trends were analysed using data averaged for each year while all correlations were performed using individual samples from each sampling time. The incidence of recruitment events for M. galloprovincialis, G. capensis and S. granularis, expressed as the number of times recruitment took place relative to the total number of observation records, were recorded over the 6 years. A recruitment event was considered to have occurred when recruit numbers peaked at least 10 times above background levels.

Statistical analysis. As insufficient replication existed within exposures within sites to allow meaningful statistical analyses with site as a factor, sites were randomly split into 2 groups and tested to determine whether significant differences existed between these groups. As no significant differences emerged ( $p>$ 0.25 ) the data for all sites were pooled for subsequent analyses.

Due to violation of the assumptions of homoscedasticity and homogeneity of variances and unequal sample sizes among groups, multi-factoral repeated measures ANOVAs could not be used to assess changes in univariate measures over time and along the gradient of wave action. As a result, where data permitted, factorial ANOVAs were used to consider the effect of time (random factor) and wave exposure (fixed factor) on percentage cover and density of adults and recruits of the dominant space occupiers and grazers. Where assumptions could not be met, Kruskal-Wallis ANOVAs by ranks were used to test each factor independently. To test the effect of wave action on Gunnarea capensis and Scutellastra granularis independently of Mytilus galloprovincialis, percentage covers of G. capensis and $S$. granularis adult and recruit densities were compared between sheltered, semi-exposed and exposed shores using all records in which $M$. galloprovincialis occupied less than $20 \%$ of primary rock space, below which the abundance of these species was unrelated to that of M. galloprovincialis. Post hoc Tukey's tests or nonparametric multiple comparisons followed all univariate analyses.

To assess the effect of wave action on all univariate measures, these were regressed against wave force. All relationships for which $\mathrm{r}^{2}>0.1$ and $\mathrm{p}<0.05$ were considered meaningful.

\section{RESULTS}

\section{Adult abundance}

Wave action had significant but opposite effects on the primary cover of the dominant space occupiers Mytilus galloprovincialis and Gunnarea capensis (Kruskal-Wallis ANOVA, p $<0.01$ in both cases), with that of $M$. galloprovincialis increasing with an increase in exposure to wave action (multiple comparisons, $\mathrm{p}<0.05$ ) while that of $G$. capensis decreased (multiple comparisons, p < 0.05) (Fig. 1). When the effect of wave action on $G$. capensis was considered independently of M. galloprovincialis, cover of G. capensis still decreased significantly with wave action (Kruskal-Wallis ANOVA $H_{2,370}=7.7, \mathrm{p}<0.05$ ). In semi-exposed and exposed areas cover of $M$. galloprovincialis increased over time (Kruskal-Wallis ANOVA, p < 0.01) while it showed no trend in sheltered areas (Kruskal-Wallis ANOVA $H_{5,554}=3.1, \mathrm{p}>$ 0.05). In contrast, G. capensis decreased significantly from 1988 to 1993 at all grades of wave action (Kruskal-Wallis ANOVA $H_{5,554}=65.2, \mathrm{p}<0.01$ ). Bare rock-space was significantly affected by an interaction between wave exposure and time (factorial ANOVA $F_{5,554}=3.6, \mathrm{p}<0.01$ ), increasing over time in sheltered areas, remaining stable in semi-exposed areas and decreasing in exposed areas (Fig. 1).

Adults of the mussel Aulacomya ater showed a significant effect of wave action (Kruskal-Wallis ANOVA $H_{2,555}=65.1, \mathrm{p}<0.01$ ) with highest densities occurring in exposed areas (Fig. 2). No effect of time was evident (Kruskal-Wallis ANOVA $H_{5,555}=8.9, \mathrm{p}>0.05$ ).

As the dominant algal species demonstrated the same patterns when analysed separately, only combined results are presented. Of the 4 algae, Ulva spp. contributed about $70 \%$ to algal biomass. A significant decline in algal cover was recorded with an increase in wave action (Kruskal-Wallis ANOVA, p $<0.05$ ), 

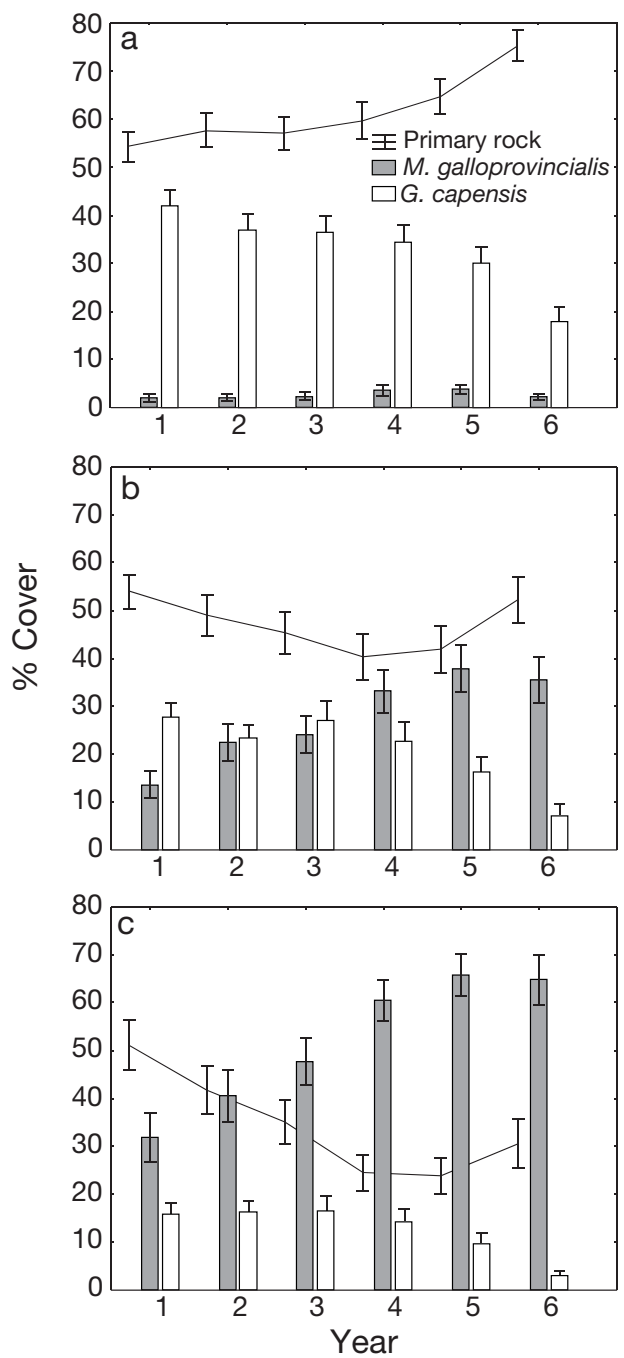

Fig. 1. Mytilus galloprovincialis, Gunnarea capensis and bare rock. Mean percent cover $( \pm \mathrm{SE})$ over time on (a) sheltered, (b) semi-exposed and (c) exposed shores. Years 1 to $6=1988$ to 1993

but no significant changes in abundance were recorded over time (Kruskal-Wallis ANOVA, p > 0.05) (Fig. 3).

The density of adults of the limpet Scutellastra granularis on primary rock was significantly affected by wave action (Kruskal-Wallis ANOVA $H_{2,554}=19.8, \mathrm{p}<$ 0.01 ) with highest densities occurring under semiexposed conditions (Fig. 4). This pattern was retained when the effect of exposure was considered independently of Mytilus galloprovincialis (Kruskal-Wallis ANOVA $H_{2,370}=34.5, \mathrm{p}<0.01$ ). Time had no statistically detectable effect on the density of primary $S$. granularis (Kruskal-Wallis ANOVA $H_{5,554}=9.2, \mathrm{p}>0.05$ ) although in semi-exposed and exposed areas densities decreased over the years until they rose sharply in Year 6.
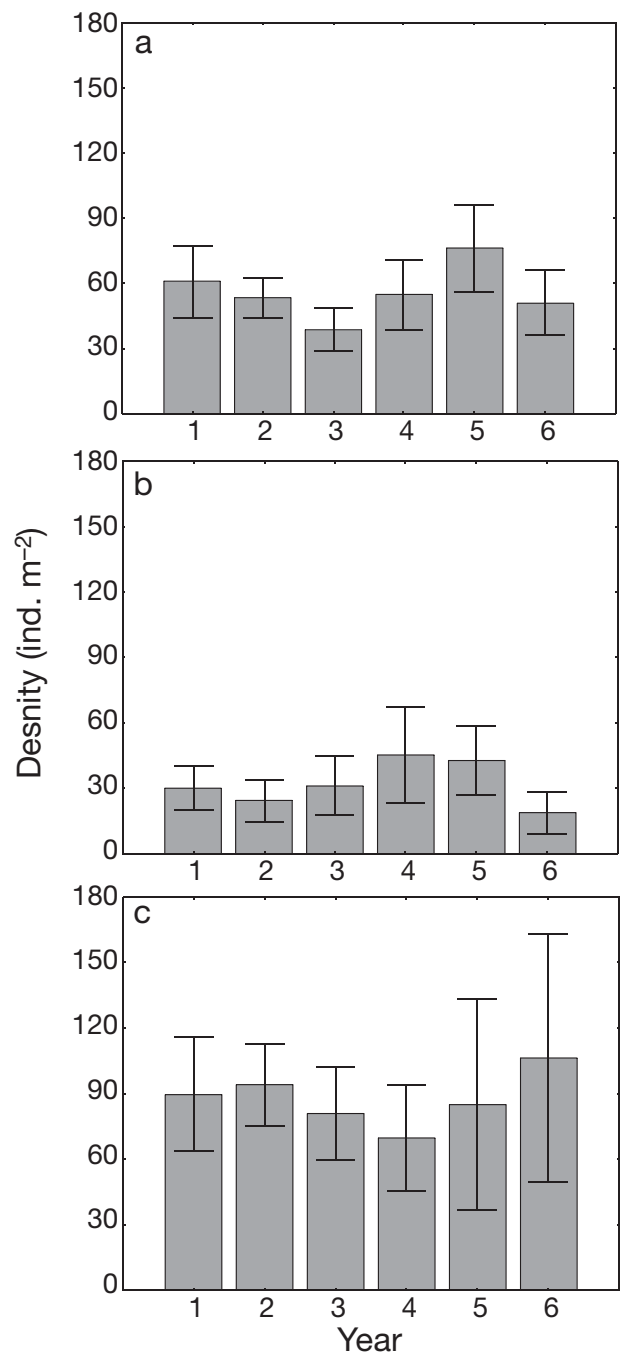

Fig. 2. Aulacomya ater. Mean density (ind. $\mathrm{m}^{-2} \pm \mathrm{SE}$ ) over time on (a) sheltered, (b) semi-exposed and (c) exposed shores. Years 1 to $6=1988$ to 1993

\section{Recruit abundance}

As with the primary cover of adults, the densities of Mytilus galloprovincialis and Gunnarea capensis recruits were significantly affected by wave action (Kruskal-Wallis ANOVA, p < 0.01) with the highest densities of $M$. galloprovincialis and the lowest densities of $G$. capensis occurring in exposed areas (multiple comparisons, p < 0.05) (Fig. 5). Significant differences were recorded in $M$. galloprovincialis recruit density in different years (Kruskal-Wallis ANOVA $H_{2,554}=19.9$, $\mathrm{p}<0.01$ ) with dense recruitment peaks occurring sporadically on semi-exposed and exposed shores, and low levels of recruitment occurring consistently in sheltered areas (Kruskal-Wallis ANOVA $H_{2,87}=52.3$, $p<0.001$; multiple comparisons, $p<0.05$ ). Inter-annual 

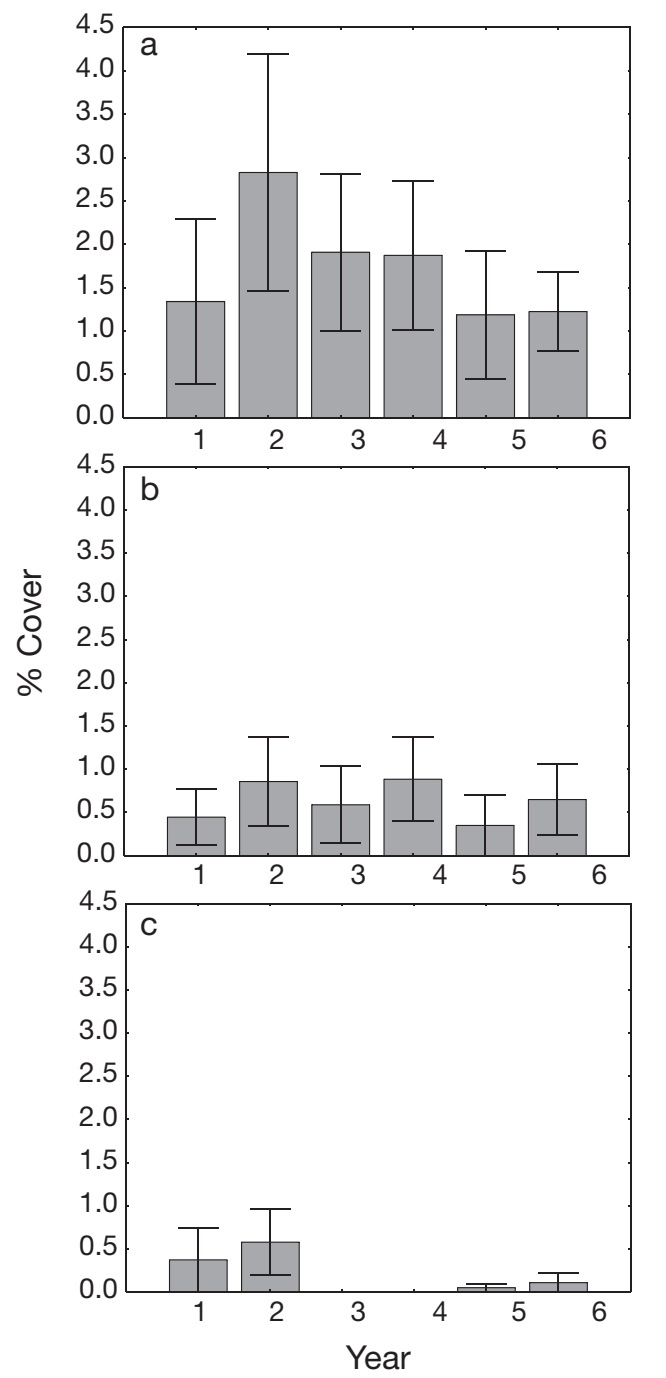

Fig. 3. Mean percent cover $( \pm \mathrm{SE})$ of dominant algal species over time on (a) sheltered, (b) semi-exposed and (c) exposed shores. Years 1 to $6=1988$ to 1993

differences in the densities of G. capensis recruits were also detected (Kruskal-Wallis ANOVA $H_{2,554}=148.7$, $\mathrm{p}<0.0001$ ) with a large recruitment peak occurring at all exposure levels in Year 2 (Fig. 5). The frequency of recruitment events was consistent among exposure levels (Kruskal-Wallis ANOVA $H_{2,87}=5.9, \mathrm{p}>0.05$ ).

The density of Aulacomya ater recruits (Fig. 6) increased significantly with wave action (Kruskal-Wallis ANOVA $H_{2,555}=59.6, \mathrm{p}<0.001$ ) with highest densities occurring in exposed areas (multiple comparisons, $\mathrm{p}<$ $0.05)$, but did not change significantly over the years (Kruskal-Wallis ANOVA $H_{5,555}=8.2, \mathrm{p}>0.05$ ).

Wave exposure had a significant effect on recruitment of the limpet Scutellastra granularis on primary rock (Kruskal-Wallis ANOVA $H_{2,554}=21.9, \mathrm{p}<0.001$ ) with semi-exposed and exposed shores supporting greater
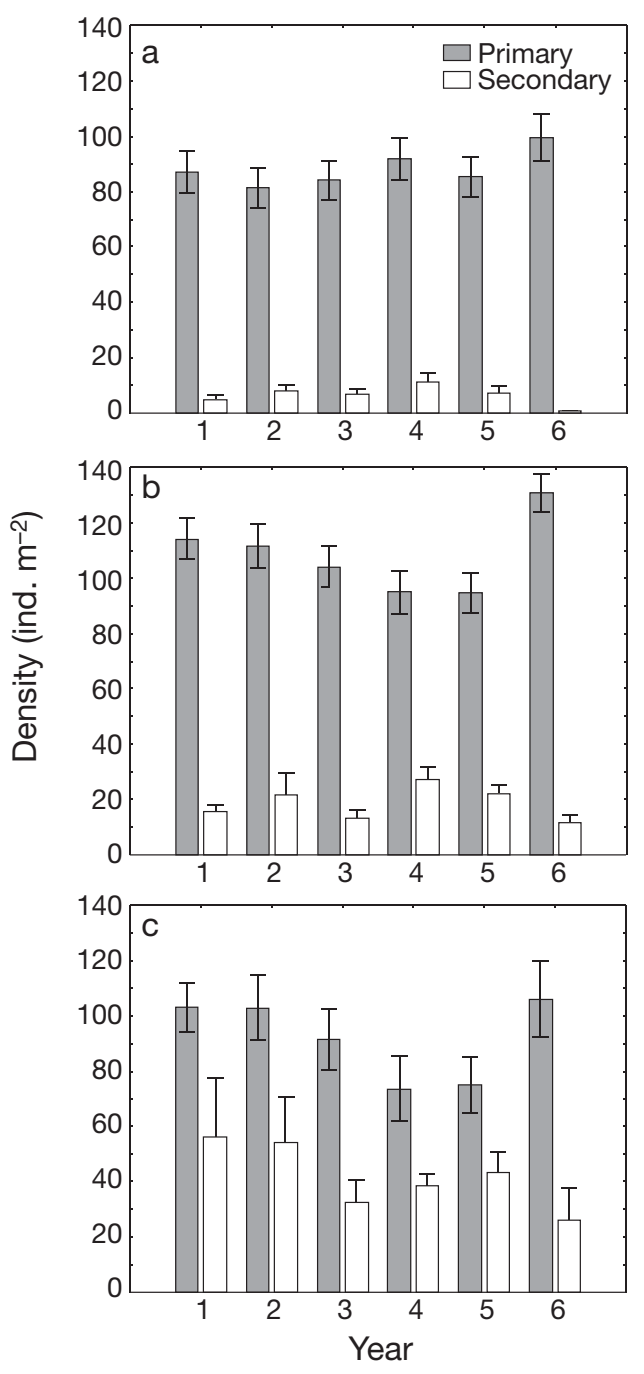

Fig. 4. Scutellastra granularis. Mean density (ind. $\mathrm{m}^{-2} \pm \mathrm{SE}$ ) of adults occupying primary and secondary space over time on (a) sheltered (b) semi-exposed and (c) exposed shores. Years 1 to $6=1988$ to 1993

densities than did sheltered shores (multiple comparisons, $\mathrm{p}<0.05$; Fig. 7). No effect of time was detected (Kruskal-Wallis ANOVA $H_{5,555}=9.0, \mathrm{p}>0.05$ ). Recruits on secondary substratum also increased significantly with wave action (Kruskal-Wallis ANOVA $H_{2,554}=315.1$, $\mathrm{p}<0.0001$; multiple comparisons, $\mathrm{p}<0.05$ ). The density of these secondary-substratum recruits was, however, affected by time (Kruskal-Wallis ANOVA $H_{2,554}=12.8, \mathrm{p}<$ $0.05)$, with an increase over the years that was most clear in exposed areas (multiple comparisons, $\mathrm{p}<0.05$; Fig. 7).

\section{Adults versus recruits versus wave action}

When recruit densities of Mytilus galloprovincialis were regressed against adult density and wave 

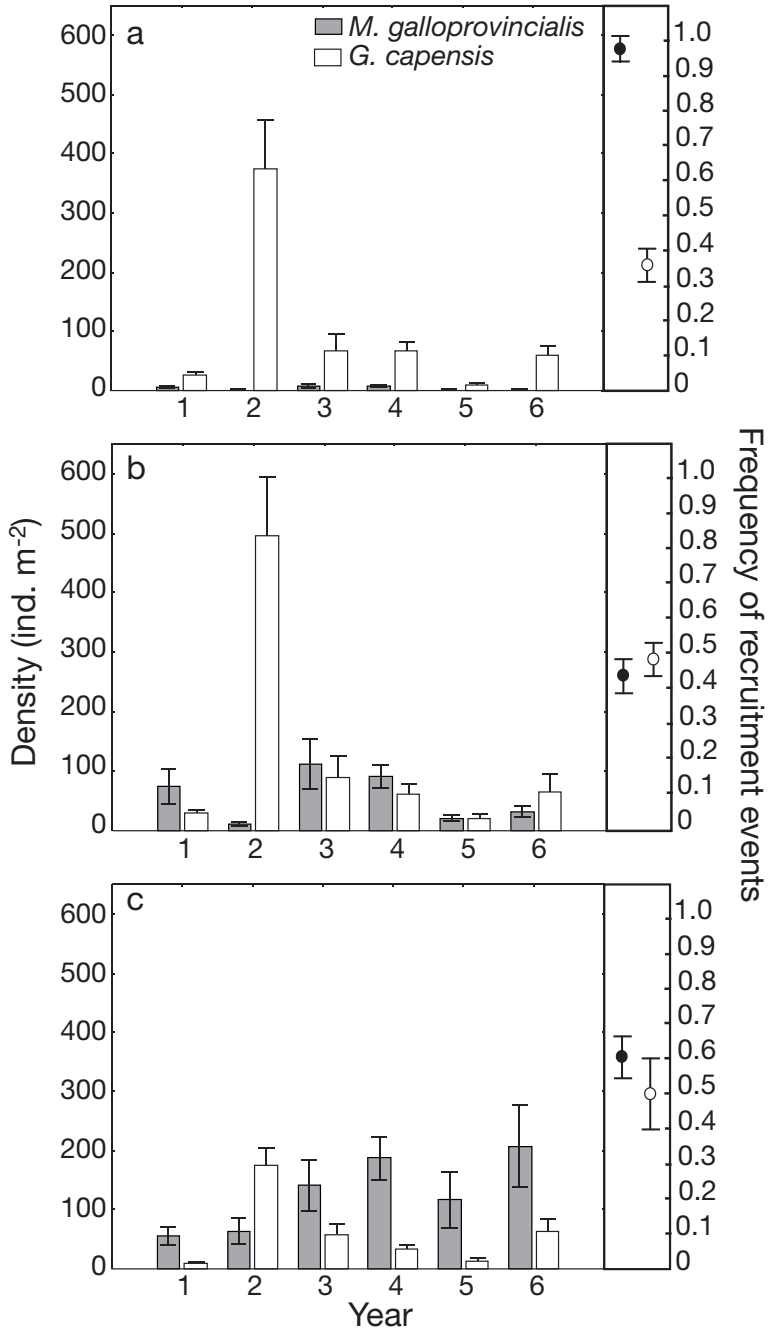

Fig. 5. Mytilus galloprovincialis and Gunnarea capensis. Mean annual recruit density (ind. $\mathrm{m}^{-2} \pm \mathrm{SE}$ ) on (a) sheltered, (b) semi-exposed and (c) exposed shores. Mean number $( \pm \mathrm{SE})$ of recruitment events as a proportion of the total number of observations for each species over that time period are shown on the right. Years 1 to $6=1988$ to 1993

force, significant positive linear relationships existed (Fig. 8a,b). The same trend emerged when percent cover of M. galloprovincialis adults was regressed against wave force (Fig. 8c). Gunnarea capensis demonstrated a very different pattern. Although recruit density of this polychaete showed a positive linear relationship with adult density, the variability in recruit density explained by this relationship was only $2 \%$ (Fig. $8 d$ ). Additionally, no relationship was found between recruit density and wave force (Fig. 8e). Adult percent cover, however, showed a significant negative linear relationship with wave force (Fig. 8f).
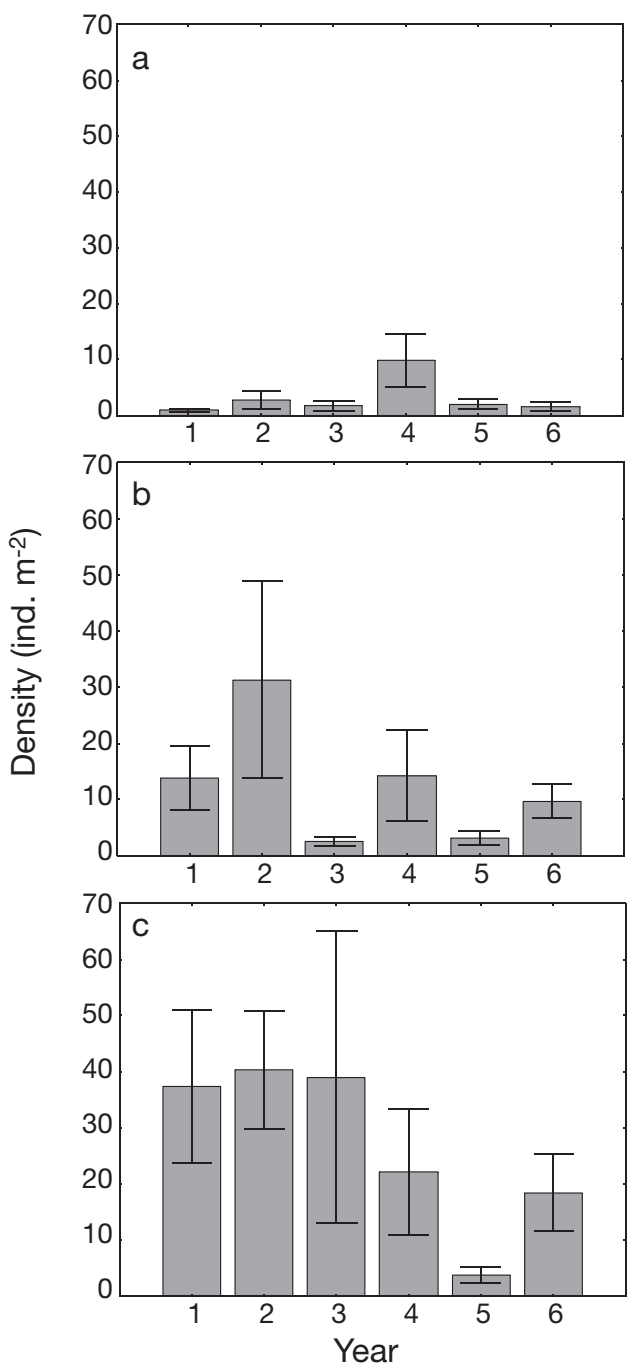

Fig. 6. Aulacomya ater. Mean annual recruit density (ind. $\mathrm{m}^{-2}$ $\pm \mathrm{SE}$ ) on (a) sheltered, (b) semi-exposed and (c) exposed shores. Years 1 to $6=1988$ to 1993

\section{Interspecific interactions}

Percentage cover of Mytilus galloprovincialis was not related to that of Gunnarea capensis on sheltered shores, but was negatively associated with it on semiexposed and exposed shores (Fig. 9). M. galloprovincialis was also negatively associated with the density of adult Scutellastra granularis on primary rock, and the strength of this negative association increased with wave action (Fig. 10). In contrast, this mussel had a positive effect on adults of $S$. granularis occurring on secondary substrata (Fig. 10), and this effect decreased at greater intensities of wave action. As with adults, a significant negative relationship was found between $S$. granularis recruits on primary substratum and M. galloprovincialis, but only on exposed shores. Sec- 

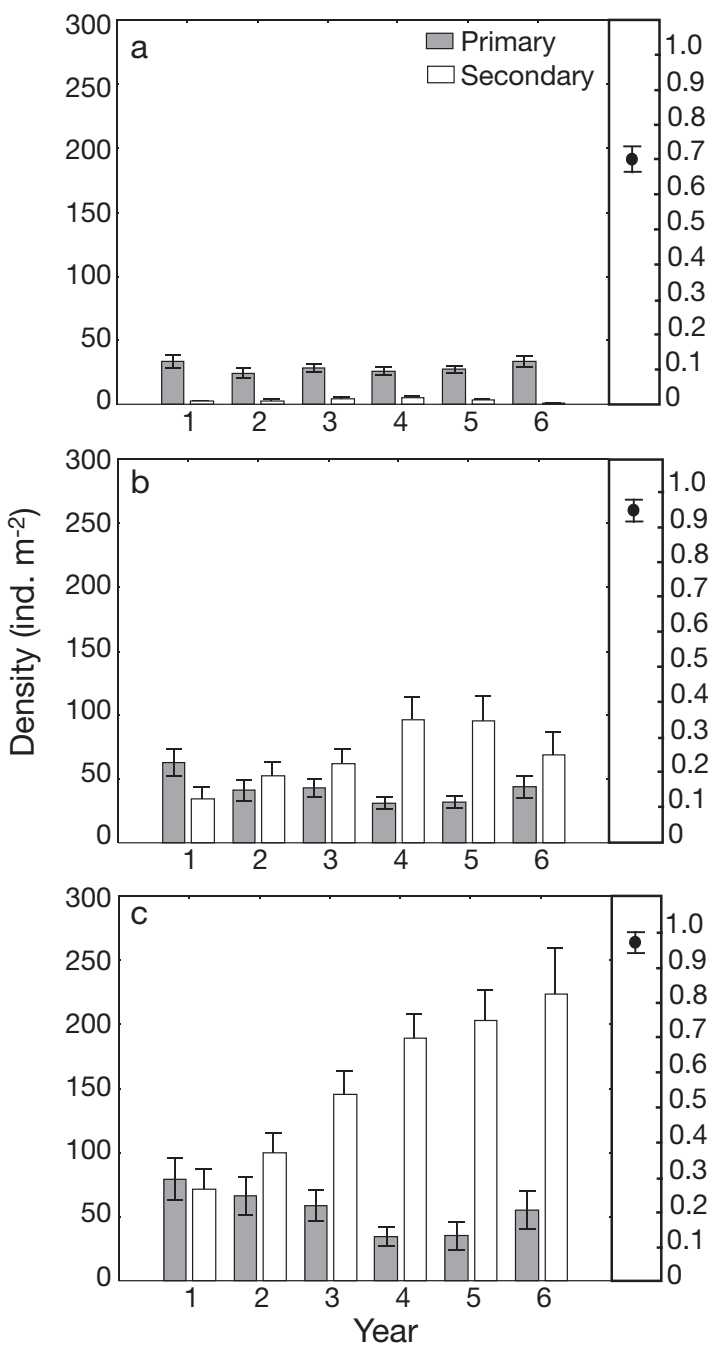

Fig. 7. Scutellastra granularis. Mean annual density (ind. $\mathrm{m}^{-2}$ $\pm \mathrm{SE}$ ) of recruits occupying primary and secondary space between 1988 and 1993 (Years 1 to 6) on (a) sheltered, (b) semiexposed and (c) exposed shores. The mean number $( \pm \mathrm{SE})$ of recruitment events for this species as a proportion of the total number of observations are given on the right

ondary-substratum recruits were positively affected by $M$. galloprovincialis at all grades of wave action (Fig. 10).

A significant and negative linear relationship was found between Gunnarea capensis and primary Scutellastra granularis adults on sheltered and semiexposed shores, but primary $S$. granularis recruits exhibited this effect on sheltered shores only (Table 2).

Analyses of the relationship between primary Scutellastra granularis adults and the dominant algal species revealed no interaction between these species on semi-exposed or exposed shores ( $p<0.05)$. On sheltered shores, however, significant negative relationships were recorded for Porphyra capensis, Caulacan- thus ustulatus, Ulva spp. and Aeodes orbitosa although the variability in algal percentage cover explained by these relationships was less than $6 \%$. The clearest pattern was that these 4 algal species were totally absent when the density of $S$. granularis exceeded 110, 97, 139 and 185 ind. $\mathrm{m}^{-2}$, respectively.

Similarly, considerations of the relationship between Gunnarea capensis and the dominant algal species revealed no interaction on semi-exposed or exposed shores ( $p>0.05)$, but on sheltered shores significant positive relationships were recorded for Ulva spp. and Caulacanthus ustulatus, but not Porphyra capensis (Table 3). However, only the relationship between $G$. capensis and C. ustulatus was deemed meaningful as the variability explained by the other correlations was less than $8 \%$ (Table 3).

\section{DISCUSSION}

The effect of wave exposure on sedentary filter feeders has been well studied; most species increase in both biomass and density with increasing exposure (McQuaid \& Branch 1984, 1985, Cáceres-Martinez et al. 1993, van Erkom Schurink \& Griffiths 1993). This relationship with wave exposure is largely due to increased food supply associated with increased water movement (Bustamante \& Branch 1996, Sanford \& Menge 2001). Recently, Steffani \& Branch (2003a,b,c) and Branch \& Steffani (2004) showed that this relation-

Table 2. Gunnarea capensis and Scutellastra granularis. Correlation statistics for the relationships between $G$. capensis and limpet adults and recruits occupying primary substratum on sheltered, semi-exposed and exposed shores

\begin{tabular}{|lcrc|}
\hline Exposure level & $\mathrm{r}^{2}$ & $\mathrm{r}$ & Significance level \\
\hline Adults & & & \\
Sheltered & 0.13 & -0.36 & $\mathrm{p}<0.0001$ \\
Semi-exposed & 0.11 & -0.34 & $\mathrm{p}<0.0001$ \\
Exposed & 0.0001 & 0.01 & $\mathrm{p}>0.5$ \\
Recruits & & & \\
Sheltered & 0.14 & -0.37 & $\mathrm{p}<0.0001$ \\
Semi-exposed & 0.02 & -0.13 & $\mathrm{p}>0.5$ \\
Exposed & 0.0008 & -0.03 & $\mathrm{p}>0.5$ \\
\hline
\end{tabular}

Table 3. Gunnarea capensis. Correlation statistics for the relationships between polychaetes and 3 algae on sheltered shores

\begin{tabular}{|lccc|}
\hline Algal species & $\mathrm{r}^{2}$ & $\mathrm{r}$ & Significance level \\
\hline Ulva spp. & 0.08 & -0.29 & $\mathrm{p}<0.0001$ \\
Caulacanthus ustulatus & 0.12 & 0.15 & $\mathrm{p}<0.01$ \\
Porphyra capensis & $>0.001$ & -0.008 & $\mathrm{p}>0.05$ \\
\hline
\end{tabular}



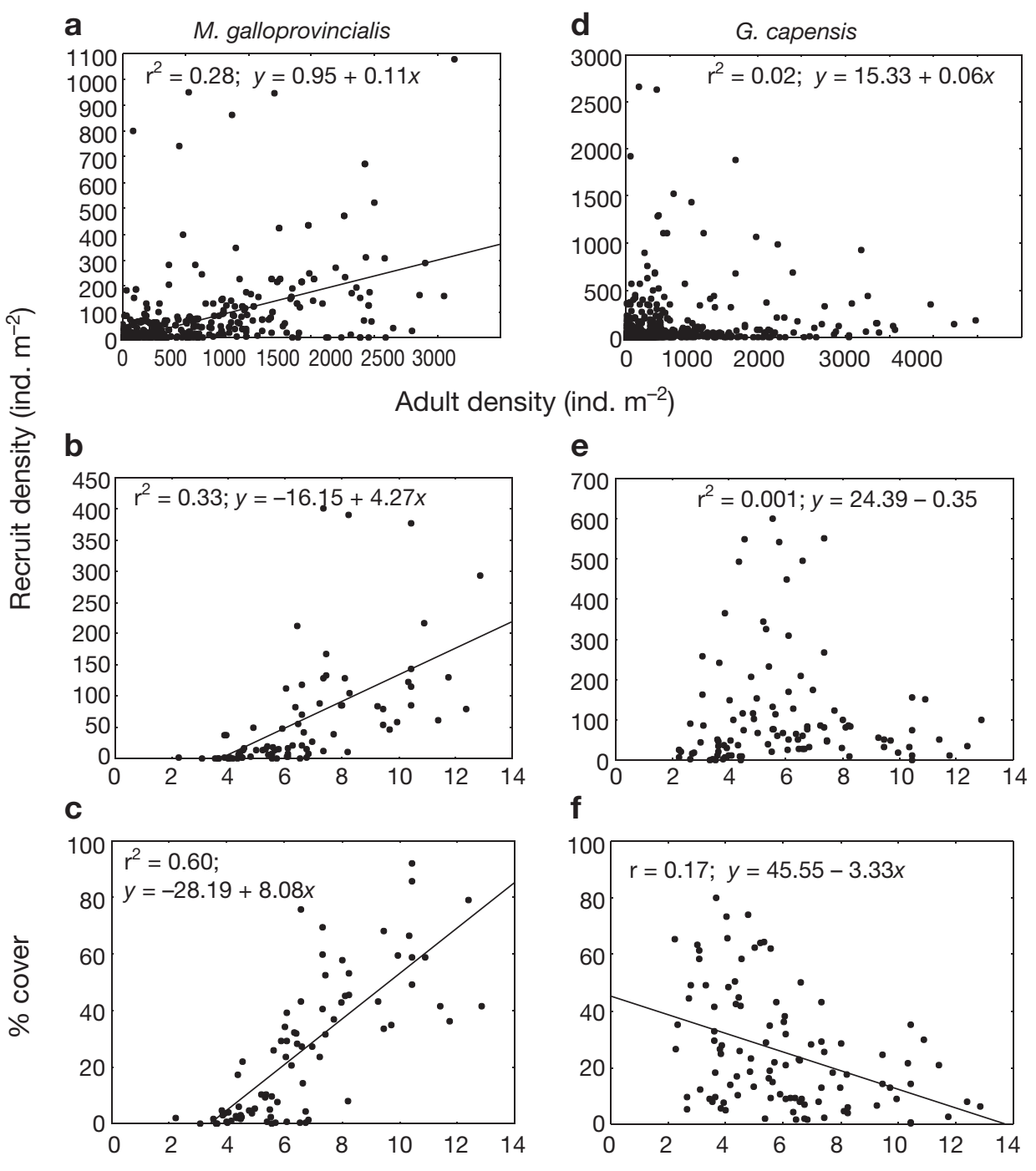

f

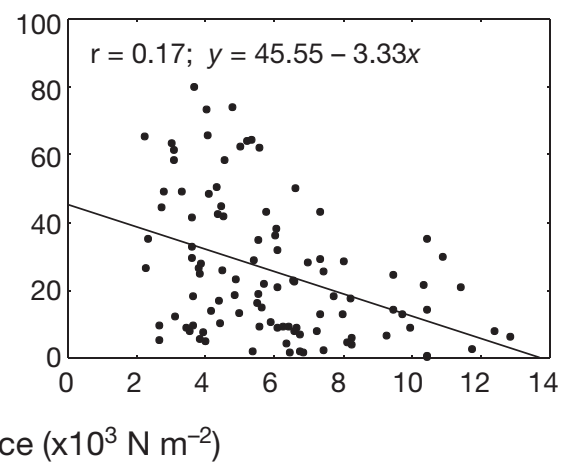

Fig. 8. (a-c) Mytilus galloprovincials and (d-f) Gunnarea capensis. Recruit density (ind. $\mathrm{m}^{-2}$ ) in relation to (a,d) adult density and $(\mathrm{b}, \mathrm{e})$ mean wave force $\left(\times 10^{3} \mathrm{~N} \mathrm{~m}^{-2}\right)$. (c,f) Adult percentage cover is also shown in relation to mean wave force $\left(\times 10^{3} \mathrm{~N} \mathrm{~m}^{-2}\right)$. Trendlines represent relationships for which $\mathrm{r}^{2}>0.1$

ship is not linear, and that under extreme wave action, biomass, density, settlement and growth rate all decrease. As the range of wave action considered by our study did not include very exposed shores, it was predicted that Mytilus galloprovincialis would increase in a simple linear manner with wave exposure. Additionally, populations were expected to remain at consistently low levels in sheltered areas while increasing over time on both semi-exposed and exposed shores as this alien became increasingly established. These predictions were upheld with both adults and recruits demonstrating substantial increases in abundance with increasing wave exposure (Figs. 1 \& 5) and populations remaining stable at low levels in sheltered areas while increasing over time on more exposed shores. This is probably a reflection of preferential settlement into conspecific beds (Cáceres-Martinez et al. 1994, Harris et al. 1998, Robinson et al. 2007a), which are themselves favoured by wave action, with both growth rate and survival following the same trend (Steffani \& Branch 2003c, T. B. Robinson unpubl. data). As a consequence of these characteristics, along with high fecundity and desiccation tolerance (van Erkom Schurink \& Griffiths 1990, Hockey \& van Erkom Schurink 1992), this invasive mussel has dramatically altered intertidal communities along the waveexposed South African west coast.

Due to the fragile nature of its sand tubes, Gunnarea capensis was expected to decrease in abundance from sheltered to exposed shores. Additionally, populations 

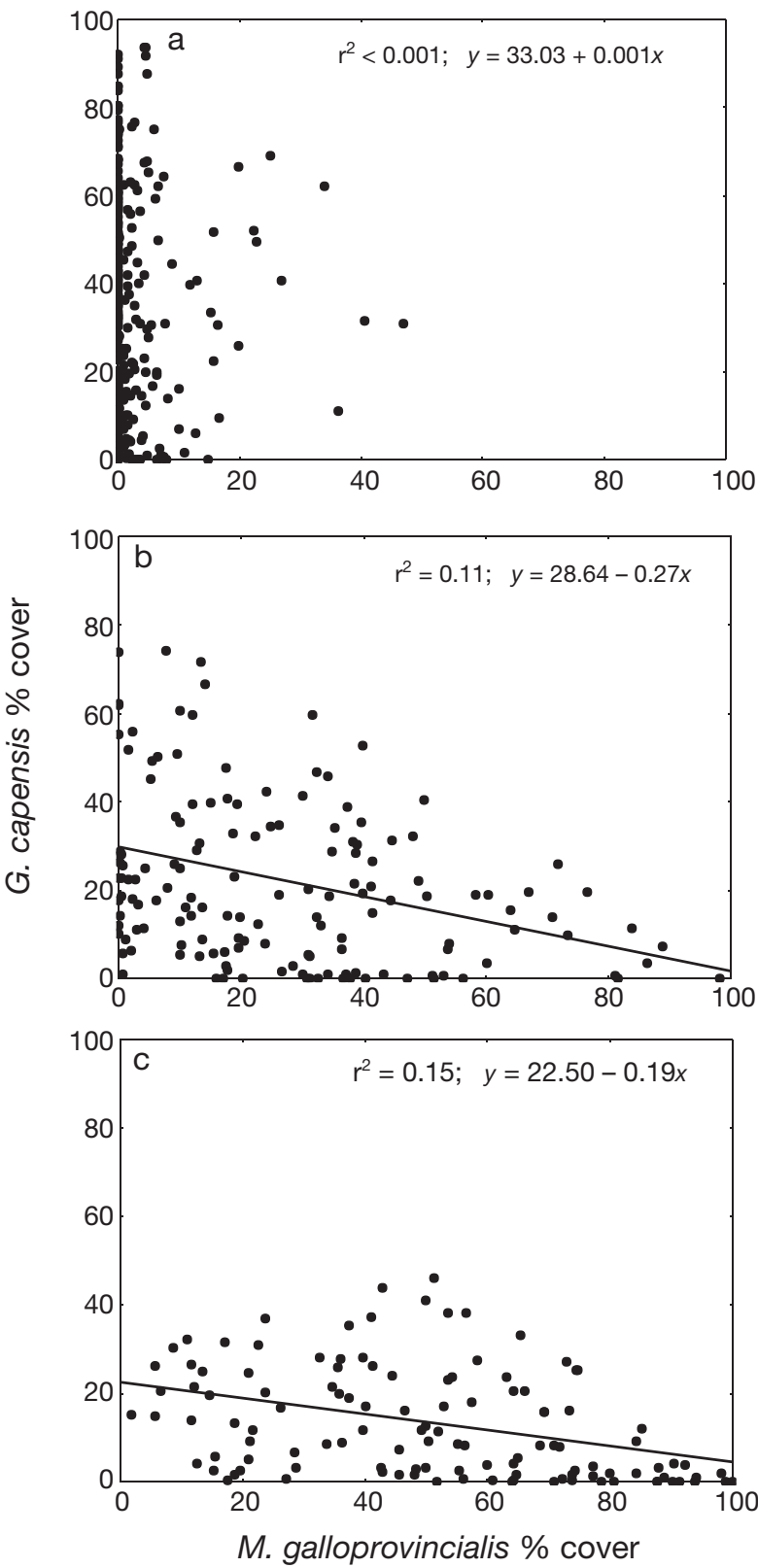

Fig. 9. Gunnarea capensis. Percent cover in relation to percent cover of Mytilus galloprovincialis on (a) sheltered, (b) semi-exposed and (c) exposed shores. Trendlines represent relationships in which $\mathrm{r}^{2}>0.1$

were expected to remain stable in sheltered areas where Mytilus galloprovincialis never attained significant numbers, but to decline over time in both semiexposed and exposed conditions as M. galloprovincialis populations increased and exerted a negative effect on G. capensis. Conforming to our predictions, the abundance of both adults and recruits of G. capensis declined with an increase in wave exposure (Figs. 1 \& 5). Similar patterns in distribution of this polychaete have been recorded along this coast by Wieters (2006).
However, contrary to expectations, adult populations declined over time at all grades of wave action. As M. galloprovincialis covered less than $5 \%$ of primary space on sheltered shores at any time, and open rock space increased there over time, it is unlikely that competition for primary space with this mussel was responsible for the observed decline. Nonetheless, the decline in G. capensis on semi-exposed and exposed shores was correlated with increasing $M$. galloprovincialis abundance (Fig. 9). Given the gregarious nature of settlement in tube-forming sabellariid worms (Pawlick 1988) the fact that recruitment of G. capensis showed no meaningful relationship with adult density was unexpected.

Wave action strongly influences grazers inhabiting the intertidal zone. Although some grazers may require wave exposure (e.g. Scutellastra argenvillei, Bustamante et al. 1995a, Bustamante \& Branch 1996), most are negatively affected by the effects of lift and drag associated with intense water movement (Denny et al. 1985). As a result, population density as well as growth and reproduction are often reduced under exposed conditions (Branch \& Cherry 1985, Branch \& Odendaal 2003). It was, thus, predicted that populations of the limpet Scutellastra granularis would decrease in density with increasing wave exposure. Additionally, Mytilus galloprovincialis was predicted to reinforce this pattern over time as it excluded $S$. granularis from rock under semi-exposed and exposed conditions. Contrary to our predictions, both adults and recruits showed the opposite trend, with densities increasing with exposure (Figs. 4 \& 7). Although unexpected, this pattern may reflect morphological features such as a streamlined shell and high tenacity (Branch \& Marsh 1978) that enable this limpet to inhabit exposed shores. Additionally, preferential settlement of S. granularis recruits under conditions of high wave action may translate into the patterns observed in adult populations. Over time, the overall population size of this limpet increased, despite adults decreasing on both semi-exposed and exposed shores (except in Year 6). Thus, the increase in total population size was probably due to increases in recruitment rather than adult survival. The density of $S$. granularis living on primary rock-space remained stable over time. Effectively, this led to an increase in crowding as open rockspace declined on semi-exposed and exposed shores with the establishment of Mytilus galloprovincialis. Furthermore, a negative relationship was recorded between $M$. galloprovincialis and primary substratum adults and recruits, the strength of which increased with increasing wave action. In contrast, secondarysubstratum populations increased because of substantial increases in recruitment, especially on exposed shores. This trend reflects the enhancement of avail- 

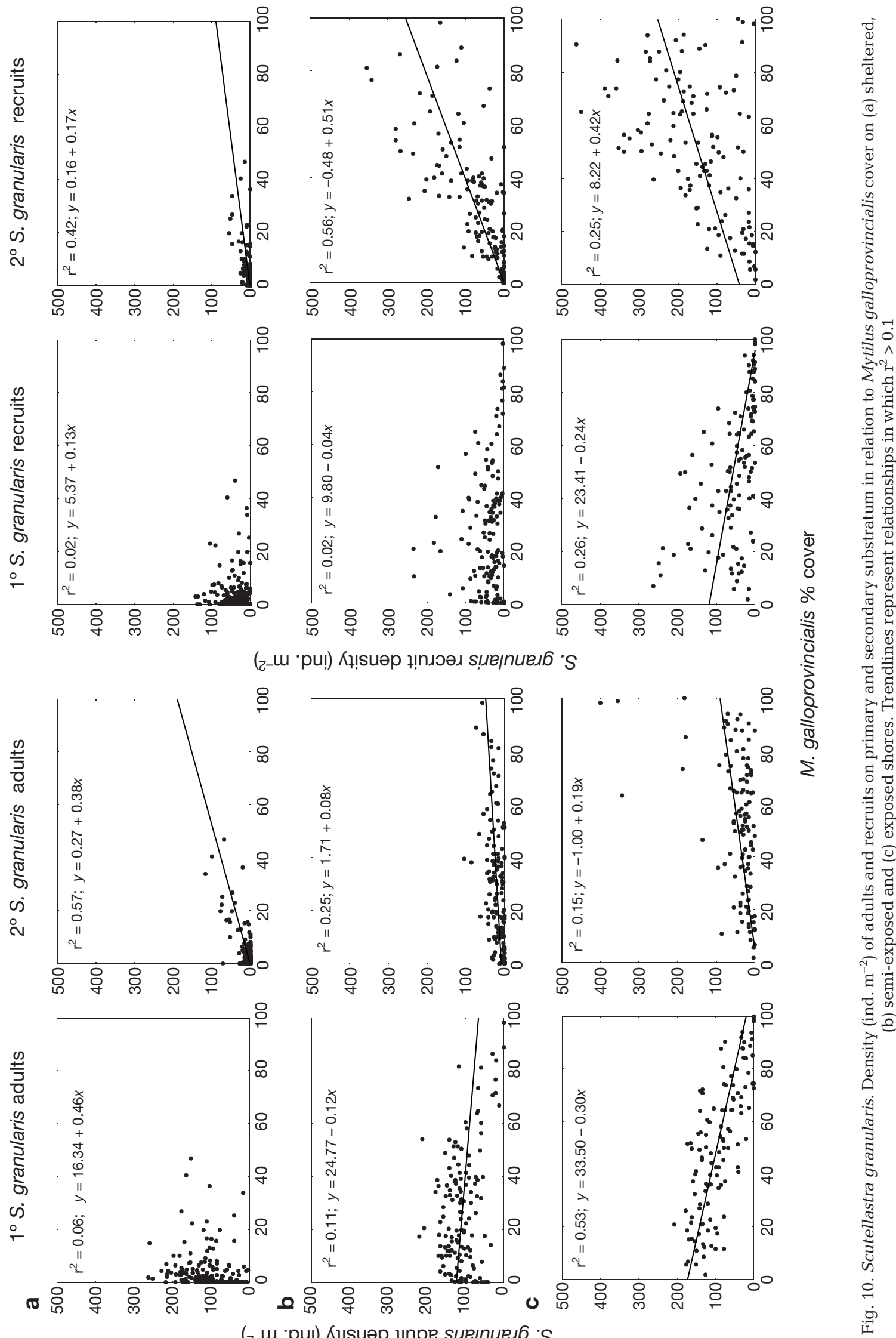

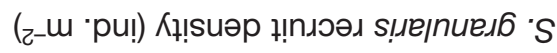
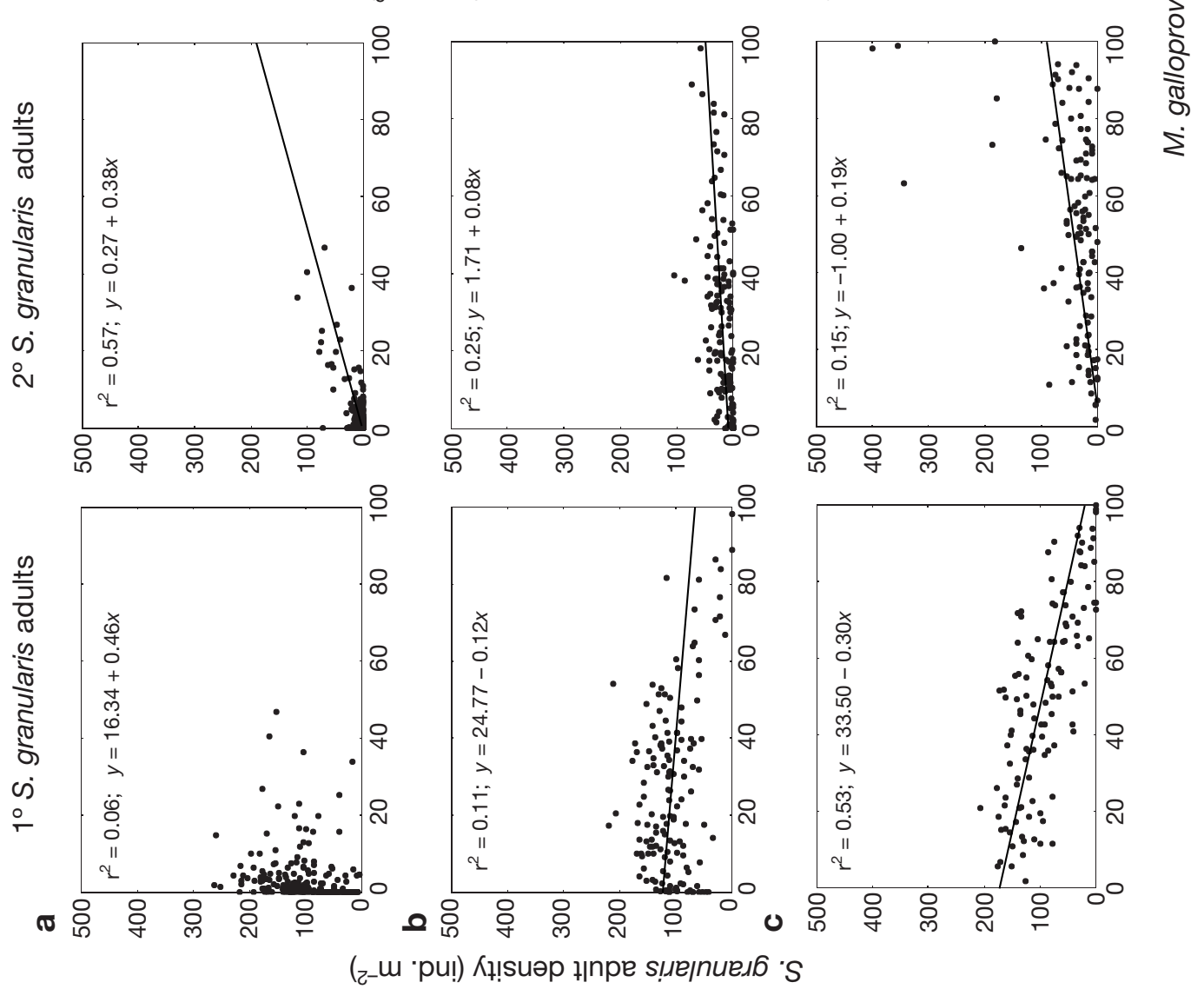
able settlement and recruitment substratum by $M$. galloprovincialis beds (Griffiths et al. 1992, Hockey \& van Erkom Schurink 1992) and mirrors the increase in abundance of this mussel over time.

As a mobile grazer, Scutellastra granularis was also affected by the other important occupant of primary space, Gunnarea capensis. A negative relationship was recorded between this polychaete and primary $S$. granularis adults and recruits on shores where low to intermediate wave exposure facilitated dominance of G. capensis.

As a filter feeder it was expected that the indigenous mussel Aulacomya ater would increase with wave exposure. However, in the presence of Mytilus galloprovincialis, the abundance of $A$. ater was predicted to remain stable on sheltered shores, decline slightly on semi-exposed shores and decrease substantially on exposed shores, as it became progressively outcompeted by the dominant alien. As expected, A. ater occurred at highest abundance on exposed shores, but populations showed no significant changes over time (Fig. 2). The same pattern was true for recruits (Fig. 6). This apparent stability of $A$. ater may reflect a balance between losses due to competition with M. galloprovincialis and population increases due to increased shelter and protection provided by M. galloprovincialis beds. M. galloprovincialis is likely to have diluted the effects of predation on the thick-shelled A. ater (Griffiths \& Seiderer 1980), partly because of its abundance, but also because it has thin shells (Steffani \& Branch 2003c) and is likely to be favoured by predators.

Direct effects of wave force on intertidal algae range from mediation of settlement (Taylor \& Schiel 2003) to damage and detachment (Denny et al. 1989) and result in a predominance of algae on sheltered shores (McQuaid \& Branch 1984, Bustamante et al. 1997). It was, thus, anticipated that algae would be less abundant at higher intensities of wave action and that this pattern would intensify over time as Mytilus galloprovincialis became established as a dominant space occupier on semi-exposed and exposed shores. Overall patterns of algal abundance showed a significant decline with increasing wave action (Fig. 3), thus, conforming to our predictions and the observations of others (McQuaid \& Branch 1984, Bustamante et al. 1997). Interestingly, no changes were recorded in abundance over time. This excludes the possibility of the invasion of $M$. galloprovincialis having a negative effect on any of the algae considered.

The suspected role of Gunnarea capensis in maintaining algal abundance on sheltered shores by hindering grazing failed to materialise. This was unexpected, as the role of tube-dwelling polychaetes in mediating algal abundance is well established (Luckenbach 1988, Harwell \& Orth 2001). A meaningful positive relationship was, however, recorded for Caulacanthus ustulatus, which recruits onto the brims or adjacent to the sandy tubes of G. capensis (authors' pers. obs.). Relatively weak negative interactions were recorded between the grazing limpet, Scutellastra granularis, and algae on sheltered shores, although it was notable that all 4 algae examined demonstrated a critical density of $S$. granularis above which they were excluded. The weak nature of these interactions was unexpected as there are numerous records of herbivorous invertebrates regulating algal communities on rocky shores (Branch 1981, Hawkins \& Hartnoll 1983, Jenkins \& Hartnoll 2001, Aguilera \& Navarrete 2007).

In conclusion, wave action played an important role not only in regulating the abundance of individual species, but also in mediating interspecific interactions. Wave exposure had positive effects on the mussels Mytilus galloprovincialis and Aulacomya ater as well as the limpet Scutellastra granularis (Fig. 11). In all cases both adult and recruit abundances were elevated by increasing wave action. Conversely, Gunnarea capensis and the 4 dominant algal species were negatively affected by wave exposure. As an aggressive invader, M. galloprovincialis increased rapidly in abundance following its introduction to the west coast of South Africa. Its establishment appears to have had negative effects on G. capensis, which has declined significantly as $M$. galloprovincialis has expanded on semi-exposed and exposed shores. M. galloprovincialis appears to have had little effect on the abundance of Aulacomya ater as this indigenous mussel was not displaced, but simply incorporated into the spreading M. galloprovincialis beds. Overall the midshore grazer $S$. granularis was positively affected by the $M$. galloprovincialis invasion, but effects on different portions of the population differed. A negative

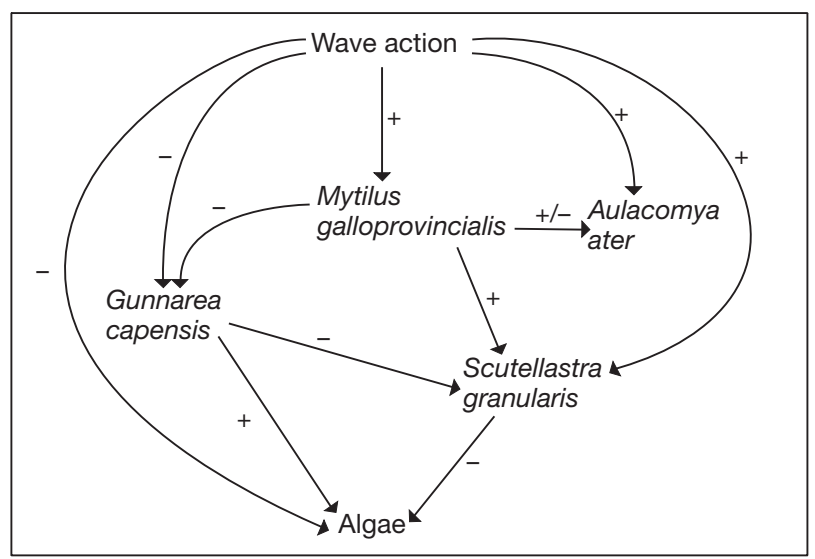

Fig. 11. A schematic representation of the interspecific interactions occurring in the mid- to low-shore areas on the South African west coast 
relationship was recorded between $M$. galloprovincialis and adults and recruits of $S$. granularis occupying primary space, the strength of which increased with wave exposure. Conversely, both adults and recruits living on secondary space were positively affected by $M$. galloprovincialis beds, which enhanced settlement substratum. Again this interaction was mediated by wave action. While this study describes patterns in the field and offers the most likely explanation for observations, experimental manipulations are required to resolve causes and effects in these species interactions.

Acknowledgements. Funding for this research was provided by the National Research Foundation, the University of Cape Town and the Andrew Mellon Foundation. Multiple debts are due to Claudio Velasquez, Alice 'Wee Tea' Linton, Sean Eekhout, Lisa Maddison and Margo Branch for years of companionable sampling — often on cold foggy nights.

\section{LITERATURE CITED}

Aguilera MA, Navarrete SA (2007) Effects of Chiton granosus (Frembly 1827) and other molluscan grazers on algal succession in wave exposed mid-intertidal rocky shores of central Chile. J Exp Mar Biol Ecol 349:84-98

Branch GM (1981) The biology of limpets: physical factors, energy flow and ecological interactions. Oceanogr Mar Biol Annu Rev 19:235-279

Branch GM, Cherry MI (1985) Activity rhythms of the pulmonate limpet Siphonaria capensis Q. \& G. as an adaptation to osmotic stress, predation and wave action. J Exp Mar Biol Ecol 87:153-168

Branch GM, Marsh AC (1978) Tenacity and shell shape in six Patella species: adaptive features. J Exp Mar Biol Ecol 34: 111-130

Branch GM, Odendaal F (2003) The effects of marine protected areas on the population dynamics of a South African limpet Cymbula oculus, relative to the influence of wave action. Biol Conserv 114:255-269

Branch GM, Steffani CN (2004) Can we predict the effects of alien species? A case-history of the invasion of South Africa by Mytilus galloprovincialis (Lamarck). J Exp Mar Biol Ecol 300:189-215

Bustamante RH, Branch GM (1996) The dependence of intertidal consumers on kelp-derived organic matter on the west coast of South Africa. J Exp Mar Biol Ecol 196: $1-28$

Bustamante RH, Branch GM, Eekhout S (1995a) Maintenance of an exceptional intertidal grazer biomass in South Africa: subsidy by subtidal kelps. Ecology 76:2314-2329

Bustamante RH, Branch GM, Eekhout S, Robertson B and others (1995b) Gradients of intertidal primary productivity around the coast of South Africa and their relationships with consumer biomass. Oecologia 102:189-201

Bustamante RH, Branch GM, Eekhout S (1997) The influence of physical factors on the distribution and zonation patterns of South African rocky-shore communities. S Afr J Mar Sci 18:119-136

Cáceres-Martínez J, Robledo JAF, Figueras A (1993) Settlement of mussels Mytilus galloprovincialis on an exposed rocky shore in Ría de Vigo, NW Spain. Mar Ecol Prog Ser 93:195-198
> Cáceres-Martínez J, Robledo JAF, Figueras A (1994) Settlement and post-larvae behaviour of Mytilus galloprovincialis: field and laboratory experiments. Mar Ecol Prog Ser 112:107-117

> Denny MN, Daniel TL, Koehl MAR (1985) Mechanical limits to size in wave-swept organisms. Ecol Monogr 55:69-102

> Denny MW, Brown V, Carrington E, Kraemer G, Miller A (1989) Fracture mechanics and the survival of wave-swept macroalgae. J Exp Mar Biol Ecol 127:211-228

Emanuel BP, Bustamante RH, Branch GM, Eekhout S, Odendaal FJ (1992) A zoogeographic and functional approach to the selection of marine reserves on the west coast of South Africa. S Afr J Mar Sci 12:341-354

> Gosling EM, Wilkins NP (1981) Ecological genetics of the mussel Mytilus edulis and Mytilus galloprovincialis on Irish coasts. Mar Ecol Prog Ser 4:221-227

Griffiths CL, Seiderer JL (1980) Rock-lobsters and mussels limitations and preferences in a predator-prey interaction. J Exp Mar Biol Ecol 44:95-109

Griffiths CL, Hockey PAR, van Erkom Schurink C, Le Roux PJ (1992) Marine invasive aliens on South African shores: implications for community structure and trophic functioning. S Afr J Mar Sci 12:713-722

Grosholz E (2002) Ecological and evolutionary consequences of coastal invasions. Trends Ecol Evol 17:22-27

Harris JM, Branch GM, Elliott BL, Currie B and others (1998) Spatial and temporal variability in recruitment of intertidal mussels around the coast of Southern Africa. S Afr J Zool 33:1-11

> Harwell MC, Orth RJ (2001) Influence of a tube-dwelling polychaete on the dispersal of fragmented reproductive shoots of eelgrass. Aquat Bot 70:1-7

Hawkins SJ, Hartnoll RG (1983) Grazing of intertidal algae by marine invertebrates. Oceanogr Mar Biol Annu Rev 21: 195-282

Hockey PAR, van Erkom Schurink C (1992) The invasive biology of the mussel Mytilus galloprovincialis on the southern African coast. Trans R Soc S Afr 48:123-139

> Jenkins SR, Hartnoll RG (2001) Food supply, grazing activity and growth rate in the limpet Patella vulgata L.: a comparison between exposed and sheltered shores. J Exp Mar Biol Ecol 258:123-139

Luckenbach MW (1986) Sediment stability around animal tubes: the roles of hydrodynamic processes and biotic activity. Limnol Oceanogr 31:779-787

> Mack RN, Simberloff D, Lonsdale WM, Evans H, Clout M, Bazzaz FA (2000) Biotic invasions: causes, epidemiology, global consequences, and control. Ecol Appl 10:689-710

McDonald JH, Seed R, Koehn RH (1991) Allozyme and morphometric characters of three species of Mytilus in the Northern and Southern Hemispheres. Mar Biol 111: 323-335

McQuaid CD, Branch GM (1984) Influence of sea temperature, substratum, and wave exposure on rocky intertidal communities: an analysis of faunal and floral biomass. Mar Ecol Prog Ser 19:145-151

> McQuaid CD, Branch GM (1985) Trophic structure of rocky intertidal communities: response to wave action and implications for energy flow. Mar Ecol Prog Ser 22:153-161

Olenin S, Minchin D, Daunys D (2007) Assessment of biopollution in aquatic ecosystems. Mar Pollut Bull 55:379-394

Palumbi SR (1984) Measurement of intertidal wave forces. J Exp Mar Biol Ecol 81:171-179

Pawlick JR (1988) Larval settlement and metamorphosis of two gregarious sabellariid polychaetes: Sabellaria alveolata compared with Phragmatopoma californica. J Mar Biol Assoc UK 68:101-124 
Ramirez SC, Cáceros-Martínez J (1999) Settlement of the blue mussel Mytilus galloprovincialis Lamarck on artificial substrates in Bahia de Todos Santos, B.C., Mexico. J Shellfish Res 18:33-39

Rawson PD, Agrawal V, Hilbish TJ (1999) Hybridization between the blue mussels Mytilus galloprovincialis and Mytilus trossulus along the Pacific coast of North America: evidence for limited introgression. Mar Biol 134:201-211

Robinson TB, Griffiths CL, McQuaid CD, Rius M (2005) Marine alien species of South Africa - status and impacts. Afr J Mar Sci 27:297-306

Robinson TB, Branch GM, Griffiths CL, Govender A (2007a) Effects of experimental harvesting on recruitment of an alien mussel Mytilus galloprovincialis. J Exp Mar Biol Ecol 345:1-11

Robinson TB, Branch GM, Griffiths CL, Govender A, Hockey PAR (2007b) Changes in South African rocky intertidal invertebrate community structure associated with the invasion of the mussel Mytilus galloprovincialis. Mar Ecol Prog Ser 340:163-171

Rius M, McQuaid CD (2006) Wave action and competitive interaction between the invasive mussel Mytilus galloprovincialis and the indigenous Perna perna in South Africa. Mar Biol 150:69-78

Sala OE, Chapin FS, Armesto JJ, Berlow E and others (2000) Global biodiversity scenarios for the year 2100. Science 287:1770-1774

Sanford E, Menge BA (2001) Spatial and temporal variation in barnacle growth in a coastal upwelling system. Mar Ecol Prog Ser 209:143-157

Shannon LV (1985) The Benguela ecosystem Part I: evolution of the Benguela, physical features and processes. Oceanogr Mar Biol Annu Rev 23:105-182

Steffani CN, Branch GM (2003a) Spatial comparisons of

Editorial responsibility: Hans Heinrich Janssen, Oldendorf/Luhe, Germany populations of an indigenous limpet Scutellastra argenvillei and an alien mussel Mytilus galloprovincialis along a gradient of wave energy. Afr J Mar Sci 25:195-212

Steffani CN, Branch GM (2003b) Temporal changes in an interaction between an indigenous limpet Scutellastra argenvillei and an alien mussel Mytilus galloprovincialis: effects of wave exposure. Afr J Mar Sci 25:213-229

Steffani CN, Branch GM (2003c) Growth rate, condition, and shell shape of Mytilus galloprovincialis: responses to wave exposure. Mar Ecol Prog Ser 246:197-209

> Steffani CN, Branch GM (2005) Mechanisms and consequences of competition between an alien mussel, Mytilus galloprovincialis, and an indigenous limpet, Scutellastra argenvillei. J Exp Mar Biol Ecol 317:127-142

Suh HL, Choi SD (1990) Two copepods (Crustacea) parasitic on the blue mussel, Mytilus galloprovincialis, from the Yongsan River Estuary in Korea. Bull Korean Fish Soc 23: 137-140

Taylor DI, Schiel DR (2003) Wave related mortality in zygotes of habitat-forming algae from different exposures in southern New Zealand: the importance of 'stickability'. J Exp Mar Biol Ecol 290:229-245

van Erkom Schurink C, Griffiths CL (1990) Marine mussels of southern Africa-their distribution patterns, standing stocks, exploitation and culture. J Shellfish Res 9:75-85

van Erkom Schurink C, Griffiths CL (1993) Factors affecting relative rates of growth in four South African mussel species. Aquaculture 109:257-273

Wieters E (2006) Benthic-pelagic coupling: rocky intertidal communities and nearshore oceanographic conditions across multiple scales. PhD thesis, University of Cape Town

> Wilkins NP, Fujino K, Gosling EM (1983) The Mediterranean mussel Mytilus galloprovincialis Lmk. in Japan. Biol J Linn Soc 20:365-374

Submitted: October 31, 2007; Accepted: June 26, 2008

Proofs received from author(s): October 16, 2008 